\title{
Marginal zone B-cell lymphoma with multiple extranodal locations in a patient with Sjögren's syndrome - a diagnostic problem
}

\author{
Chłoniak strefy brzeżnej z komórek typu B z licznymi lokalizacjami pozawęzłowymi \\ u pacjentki z zespotem Sjögrena - problem diagnostyczny
}

\author{
Marta Domżalska ${ }^{1}$, Żaneta Smoleńska ${ }^{1}$, Zenobia Czuszyńska ${ }^{1}$, Katarzyna Gałecka ${ }^{1}$, \\ Wojciech Biernat ${ }^{2}$, Andrzej Mital ${ }^{3}$, Zbigniew Zdrojewski ${ }^{1}$ \\ ${ }^{1}$ Department of Internal Medicine, Connective Tissue Diseases and Geriatrics, Medical University of Gdańsk, Gdansk, Poland \\ ${ }^{2}$ Chair and Department of Pathomorphology, Medical University of Gdańsk, Gdansk, Poland \\ ${ }^{3}$ Department of Haematology and Transplantation, Medical University of Gdańsk, Gdansk, Poland
}

Key words: lymphoma, respiratory tract, Sjögren's syndrome.

Słowa kluczowe: chłoniak, układ oddechowy, zespół Sjögrena.

\section{Sum mary}

Sjögren's syndrome is a chronic autoimmune disease characterized by the presence of lymphocytic infiltrates in exocrine glands, mainly salivary and lacrimal glands, which result in xerophthalmia and xerostomia. About half of the patients develop systemic complications, including lymphoproliferative disorders.

We report a case of a 27-year-old woman with a diagnosis of Sjögren's syndrome and a suspicion of respiratory system involvement in the course of granulomatosis with polyangiitis. Histopathological examination of a skin lesion suggested marginal zone B-cell lymphoma. After pathological and immunohistochemical evaluation of all available previous biopsy samples and the medical documentation the diagnosis of extranodal marginal zone B-cell lymphoma stage IV according to the Ann Arbor classification was rendered. The patient was referred to the Department of Haematology and was treated with R-CVP (cyclophosphamide, vincristine, prednisone, rituximab).

\section{Introduction}

Sjögren's syndrome is a chronic autoimmune disease leading to damage of the exocrine glands, mainly salivary and lacrimal. On histopathology examination inflammatory infiltrations are found, consisting of mononuclear cells with CD4+ T-cell predominance. In labora-

\section{Streszczenie}

Zespół Sjögrena jest przewlekłą chorobą autoimmunologiczną charakteryzującą się obecnością nacieków limfocytarnych w gruczołach egzokrynnych, głównie ślinowych i łzowych, co objawia się suchością jamy ustnej i oczu. U około połowy pacjentów z pierwotnym zespołem dochodzi do rozwoju powikłań narządowych, w tym chorób limfoproliferacyjnych.

W pracy opisano przypadek 27-letniej pacjentki z rozpoznanym zespołem Sjögrena, u której podejrzewano zajęcie układu oddechowego w przebiegu ziarniniakowatości z zapaleniem naczyń. Na podstawie wycinka pobranego ze zmienionej skóry u chorej wysunięto podejrzenie chłoniaka strefy brzeżnej z komórek typu B. Po weryfikacji patomorfologicznej i immunohistochemicznej wszystkich dotychczasowych preparatów histopatologicznych oraz analizie dokumentacji medycznej $u$ chorej rozpoznano pozawęzłowego chłoniaka strefy brzeżnej z komórek typu B w stopniu zaawansowania IV wg klasyfikacji Ann Arbor. Chorą skierowano do dalszego leczenia w Klinice Hematologii, gdzie zastosowano leczenie wg schematu R-CVP (cyklofosfamid, winkrystyna, prednizon, rytuksymab).

tory test results the following are found: anti-Ro/SS-A and anti-La/SS-B antibodies, hypergammaglobulinaemia, rheumatoid factor, decreased concentration of C4 complement component and increased values of inflammatory state parameters.

Two forms of Sjögren's syndrome can be distinguished: primary, occurring as a separate disease entity;

Address for correspondence:

Marta Domżalska, Department of Internal Medicine, Connective Tissue Diseases and Geriatrics, Medical University of Gdańsk, Dębinki 7 , 80-211 Gdańsk, Poland, e-mail: marta.domzalska@gmail.com

Submitted: 28.07.2014 
and secondary, accompanying other systemic autoimmune diseases. It is estimated that primary Sjögren's syndrome develops in 0.05 to $1 \%$ of the population. The prevalence varies significantly, depending on the selection of the study group and accepted classification criteria [1-4].

Despite the fact that the disease is associated mainly with symptoms and signs of eye and mouth dryness, the possibility should be kept in mind of involvement of other exocrine glands, e.g. in the alimentary and respiratory systems and other internal organs. The lesions can also develop in the kidneys, joints, blood vessels, nervous system and the skin.

In primary Sjögren's syndrome a significantly higher incidence of lymphoma development is observed, compared with the general population [5-7]. It is estimated that the 10-year risk of developing a lymphoma in this population is 4\% [5]. In these patients, most frequently non-Hodgkin lymphomas develop, mainly marginal zone B-cell lymphomas (MZL), among which splenic B-cell marginal zone lymphoma (SMZL), nodal marginal zone lymphoma (NMZL) and mucosa-associated lymphoid tissue (MALT) lymphoma can be distinguished.
The most frequent locations include the salivary glands, but malignant transformation occur can also in other organs $[1,5]$. These tumours usually have a slow and oligosymptomatic course.

\section{Case report}

A female patient, aged 27 years, with Sjögren's syndrome diagnosed in 2006, based on the American-European Consensus Group criteria of 2002, was referred to the Department of Internal Diseases, Connective Tissue Diseases and Geriatrics, Medical University of Gdańsk in July 2012, in emergency, due to dyspnoea caused by pressure exerted by the neck tumour on the trachea. Under outpatient conditions, based on the results of imaging and histological examinations a suggestion of granulomatosis with polyangiitiswas put forward. The course of the disease (from 2001 to 2010) and treatment as yet are presented in Table I.

On the admission to the Department the general condition of the patient was good. She reported dyspnoea, mainly on effort, generalised arthralgia, blanching of the hands and feet due to cold and development of nodular

Table I. Disease course and treatment in the years 2001-2010 in a patient with Sjögren's syndrome

\begin{tabular}{|c|c|c|c|c|}
\hline Year & Symptoms and signs & $\begin{array}{l}\text { Abnorma-lities } \\
\text { in laboratory } \\
\text { tests }\end{array}$ & Imaging and histological examinations & Treatment \\
\hline $\begin{array}{l}2001- \\
2005\end{array}$ & $\begin{array}{l}\text { mouth dryness, pronounced } \\
\text { carious teeth lesions }\end{array}$ & 个ESR & & \\
\hline 2006 & $\begin{array}{l}\text { signs as above } \\
\text { left lower limb paresis episode, } \\
\text { which regressed spontaneously }\end{array}$ & $\begin{array}{l}\text { high values of } \\
\text { ANA, and SS-A, } \\
\text { SS-B antibo- } \\
\text { dies, } \\
\text { 个ESR }\end{array}$ & $\begin{array}{l}\text { histological examination of the right } \\
\text { parotid gland and regional lymph nodes - } \\
\text { in the parotid gland: picture of advanced } \\
\text { Sjögren's syndrome, in the regional lymph } \\
\text { nodes: pronounced reactive changes }\end{array}$ & $\begin{array}{l}\text { prednisone } \\
\text { 10-30 mg/day } \\
\text { chloroquine } \\
250 \mathrm{mg} / \text { day }\end{array}$ \\
\hline 2008 & $\begin{array}{l}\text { chronic cough, recurrent respi- } \\
\text { ratory tract infections; hospita- } \\
\text { lisation due to pneumonia }\end{array}$ & & $\begin{array}{l}\text { chest CT - presence of cysts in the lungs } \\
\text { and an infiltration narrowing the trachea; } \\
\text { no enlarged lymph nodes were found }\end{array}$ & $\begin{array}{l}\text { prednisone } \\
10-30 \mathrm{mg} / \text { day }\end{array}$ \\
\hline 2009 & $\begin{array}{l}\text { increasing dyspnoea; periodi- } \\
\text { cally arthralgia, alternatingly } \\
\text { occurring constipation and } \\
\text { diarrhoea, nausea, abdominal } \\
\text { pain }\end{array}$ & & $\begin{array}{c}\text { CT of the chest and neck - a mass bulging } \\
\text { into the tracheal lumen, no enlarged } \\
\text { lymph nodes } \\
\text { histological examination of a subglottic } \\
\text { specimen - chronic inflammatory process } \\
\text { without malignant structure }\end{array}$ & $\begin{array}{l}\text { micro-laryngosco- } \\
\text { py with subglottic } \\
\text { infiltrate removal by } \\
\text { means of a } \mathrm{CO}_{2} \text { laser } \\
\text { (clinical improve- } \\
\text { ment); } \\
\text { steroid therapy as } \\
\text { above }\end{array}$ \\
\hline 2010 & $\begin{array}{l}\text { appearance of a nodular } \\
\text { change on the hard palate and } \\
\text { subcutaneous nodules of dia- } \\
\text { meter up to } 1 \mathrm{~cm} \text { in the region } \\
\text { of the left scapula and above } \\
\text { the upper lip; periodically arth- } \\
\text { ralgia; recurrence of inspiratory } \\
\text { dyspnoea }\end{array}$ & $\begin{array}{l}\text { presence of } \\
\text { SS-A and SS-B } \\
\text { antibodies; no } \\
\text { ANCA were } \\
\quad \text { found }\end{array}$ & $\begin{array}{c}\text { CT of the neck - a tracheal infiltration } \\
\text { was found, significantly narrowing the } \\
\text { tracheal lumen } \\
\text { histological examination of the nodular } \\
\text { lesion from the hard palate - lymphocytic } \\
\text { infiltration with the presence of macro- } \\
\text { phages, suggesting granulomatosis with } \\
\text { polyangiitis (GPA) }\end{array}$ & $\begin{array}{l}\text { prednisone } \\
10 \mathrm{mg} / \text { day }\end{array}$ \\
\hline
\end{tabular}


changes in the skin in the region of the left scapula and above the upper lip. Besides that, the patient reported body weight loss by about $4 \mathrm{~kg}$ over the last two months. Before the admission to the Department she was treated with prednisone in a $10 \mathrm{mg}$ daily dose.

Physical examination revealed the following abnormalities: traction on the region of the jugular notch during breathing, funnel chest, dry rales over the lungs on auscultation, reticular livedo on the lower extremities, enlarged isolated lymph nodes along the sternocleidomastoid muscle, subcutaneous nodules above the left scapula and above the upper lip (of diameter up to $1 \mathrm{~cm}$ ) and numerous carious defects of the teeth. The examination of peripheral joints, apart from pain on pressure of the knee, ankle and wrist joints, demonstrated no abnormalities.

During the hospitalisation of the patient in the Department chest X-ray examination was performed, which revealed a tissue mass of several centimetres in diameter, bulging into the tracheal lumen, bilateral bronchiectases, dispersed emphysematous bullae and also ground glass areas and small nodules in both

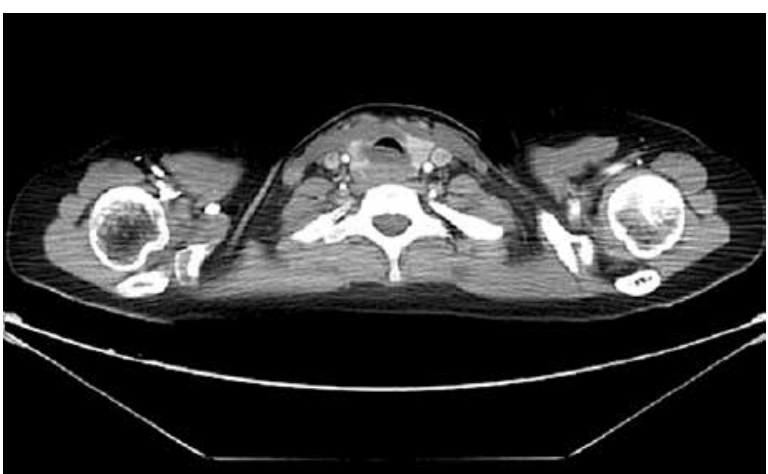

Fig. 1. Tissue mass bulging into the tracheal lumen.

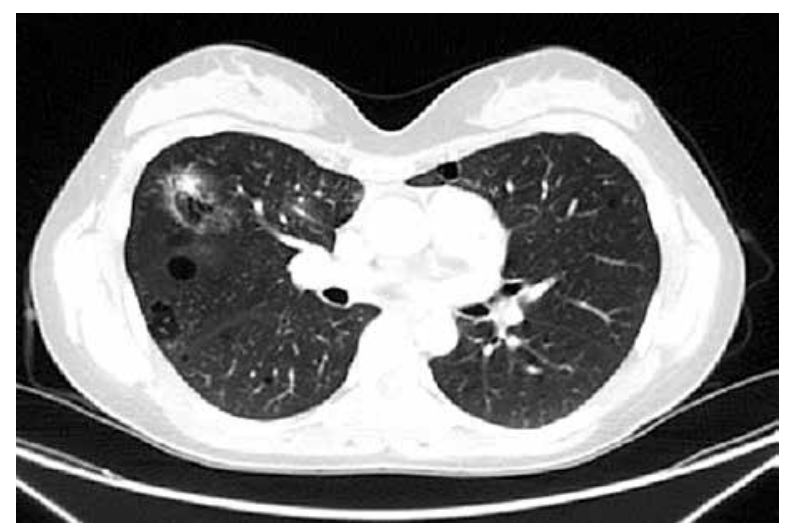

Fig. 2. Bronchiectases, emphysematous bullae. Ground glass areas and small nodules in both lungs. Isolated, non-characteristic lymph nodes in the mediastinum, the largest of $4 \times 9 \mathrm{~mm}$ dimensions. lungs, a disintegrating infiltration of $19 \times 21 \mathrm{~mm}$ dimensions in the $10^{\text {th }}$ segment of the right lung, and isolated, non-characteristic lymph nodes in the mediastinum, the largest of $4 \times 9 \mathrm{~mm}$ dimensions (Figs. 1 and 2). Bronchofibroscopy demonstrated a polycyclic nodular lesion on the posterior wall of the trachea, about $1 \mathrm{~cm}$ below the vocal cords - sections and bronchoalveolar lavage fluid were taken. Besides that a section was taken from the skin lesion above the left scapula.

On laboratory tests the following were found: increased ESR (erythrocyte sedimentation rate) value $(57 \mathrm{~mm} / \mathrm{h})$ with normal CRP (C-reactive protein) values (3.5 $\mathrm{mg} / \mathrm{l})$. The remaining test results were as follows: $\beta 2$-microglobulin $3.0 \mathrm{mg} / \mathrm{l}$, LDH (lactate dehydrogenase) $224 \mathrm{U} / \mathrm{l}$, C4 complement component $0.02 \mathrm{~g} / \mathrm{l}$ (normal value 0.1-0.4 g/l), antinuclear antibodies titre $1: 2560$, antibodies: SS-A/Ro $3.85 \mathrm{U} / \mathrm{ml}$ (normal value $<0.9 \mathrm{U} / \mathrm{ml}$ ), SS-B/La $9.88 \mathrm{U} / \mathrm{ml}$ (normal value $<0.9 \mathrm{U} / \mathrm{ml}$ ). No abnormalities were found in peripheral blood count.

In view of planned immunosuppressive treatment and a history of contact with tuberculosis, chemoprophylaxis was administered (isoniazid $300 \mathrm{mg}$ daily) until obtaining of the BAL examination result. During the stay in the Department the patient was given three methylprednisolone pulses (Solu-Medrol) of $500 \mathrm{mg}$ each, obtaining a reduction of dyspnoea and improvement of physical fitness. The next hospitalisation of the patient was scheduled, in order to continue the treatment.

The obtained results of the examinations failed to confirm the diagnosis of granulomatosis with polyangiitis (GPA). Antibodies against cytoplasm of neutrophils were absent. On histological examination of the tracheal lesion biopsy specimen a profuse inflammatory infiltrate was found, without typical inflammatory changes in the blood vessels and epithelial granulomata. In the section taken from the skin lesion on the back, lesions were found, which could have corresponded to marginal zone B-cell lymphoma - an infiltrate of small centrocyte-like lymphocytes (CCL) of phenotype CD20+, CD3-, bcl2+, CD10-, CD15-, Ki67 20\% (Figs. 3 and 4).

The patient was readmitted to the Department in order to assess the degree of lymphoproliferative disease progression and for haematological consultation. In the immunophenotypization of peripheral blood lymphocytes no lymphoma cells were found. All the biopsy specimens taken as yet (sections from the salivary gland, trachea and hard palate) were re-examined - lymphocytic infiltrations were found penetrating and destroying the epithelial structures of the salivary glands, with B-cell phenotype (CD20+, CD3-, bcl2+, absence of lg $\kappa / \lambda)$.

Based on the whole clinical picture, histological reassessment and immunohistochemical verification, the patient was diagnosed with extranodal marginal zone 

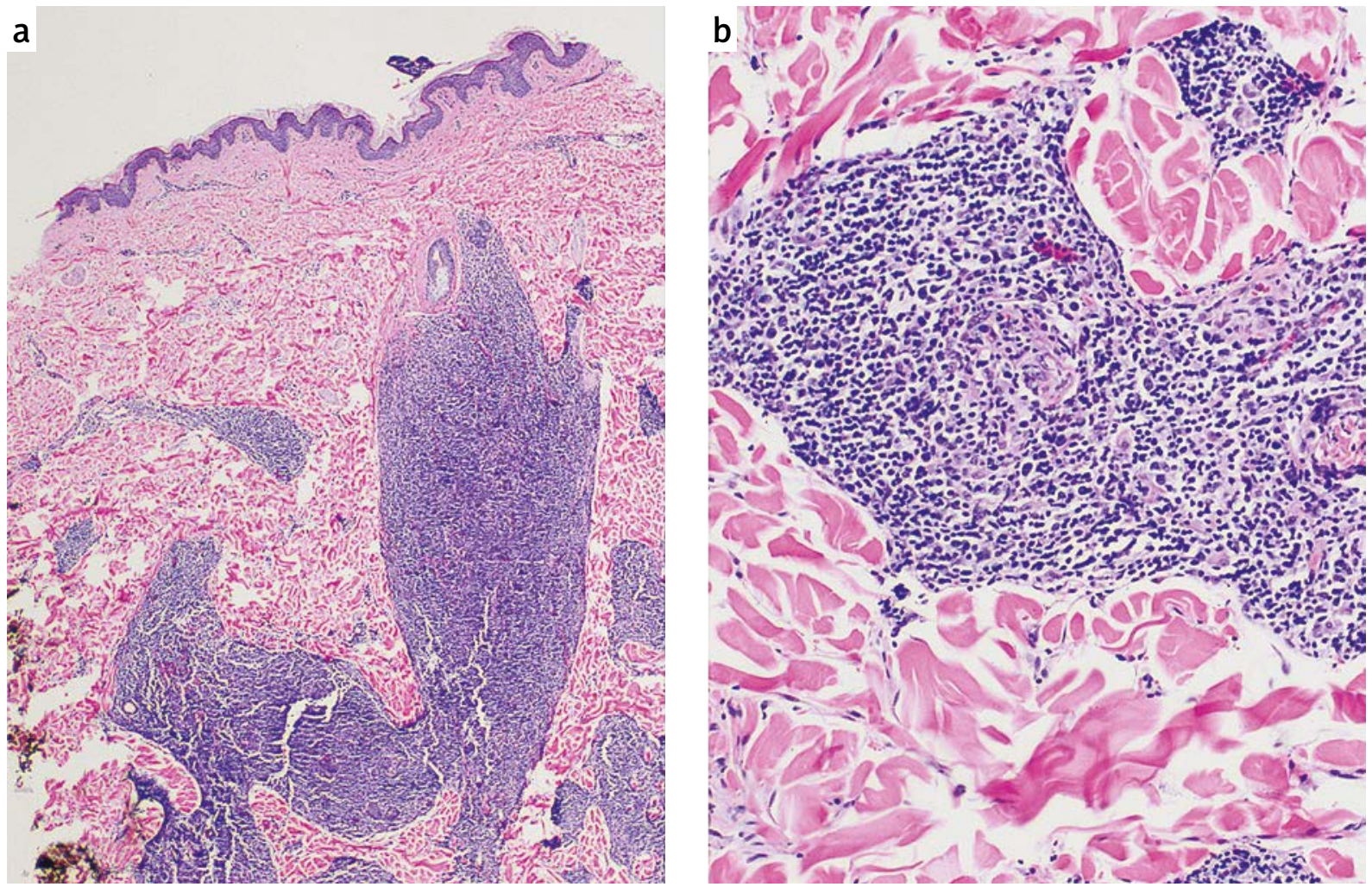

Fig. 3. Marginal zone B-cell lymphoma. Infiltration in the skin takes the form of dense, nodular aggregates of medium-size lymphocytes, more dense in the deeper skin layers ("bottom-rich") (a). They aggregate around the residual structure of reactive lymphatic follicles (b).

B-cell lymphoma in progression grade IV according to the Ann Arbor classification.

The patient was referred for further treatment in the Department of Haematology, where, in October 2010, the treatment was started according to the R-CVP (cyclophosphamide, vincristine, prednisone, rituximab) regimen. After the first treatment cycle a significant clinical improvement was observed, while after 4 cycles, complete regression of respiratory system changes was demonstrated on control chest CT examination. Regression of the skin lesions was also observed. The patient received altogether six R-CVP chemotherapy cycles, after which maintenance therapy was administered with rituximab in a $375 \mathrm{mg} / \mathrm{m}^{2}$ dose s.c., administered every two months for two years. The treatment was completed in January 2013. On control chest CT examination (January 2013) complete remission persisted. The patient was referred to the Haematology Outpatient Clinic, University Clinical Centre in Gdańsk for further follow-up.

\section{Discussion}

In primary Sjögren's syndrome a significantly higher incidence of lymphomas is observed, compared with the general population [5-7]. In the literature, a relationship has been described between persistent activation of lymphocytes caused by chronic immunological stimulation and their secondary malignant transformation $[8,9]$. The relationship between these two disease entities has been reported for several decades. Lymphoproliferative syndromes are currently regarded as the most dangerous complications of Sjögren's syndrome. loannidis et al. in a study conducted in 723 patients with Sjögren's syndrome demonstrated that one out of every five fatal cases was due to lymphoma development [5]. The mean time from making the diagnosis of Sjögren's syndrome to the final diagnosis of lymphoma is 7.5 years $[7,10]$. The changes can be limited for many years to one location and can undergo spontaneous remissions [10].

The slow and oligosymptomatic progression of the malignant process causes that the diagnosis is frequently made late, even after several years of the disease course; therefore patients with Sjögren's syndrome should be carefully followed up and subjected to frequent follow-up examinations. Patients with such signs as generalised lymphadenopathy, splenomegaly, chronic salivary gland oedema, changes in the respira- 

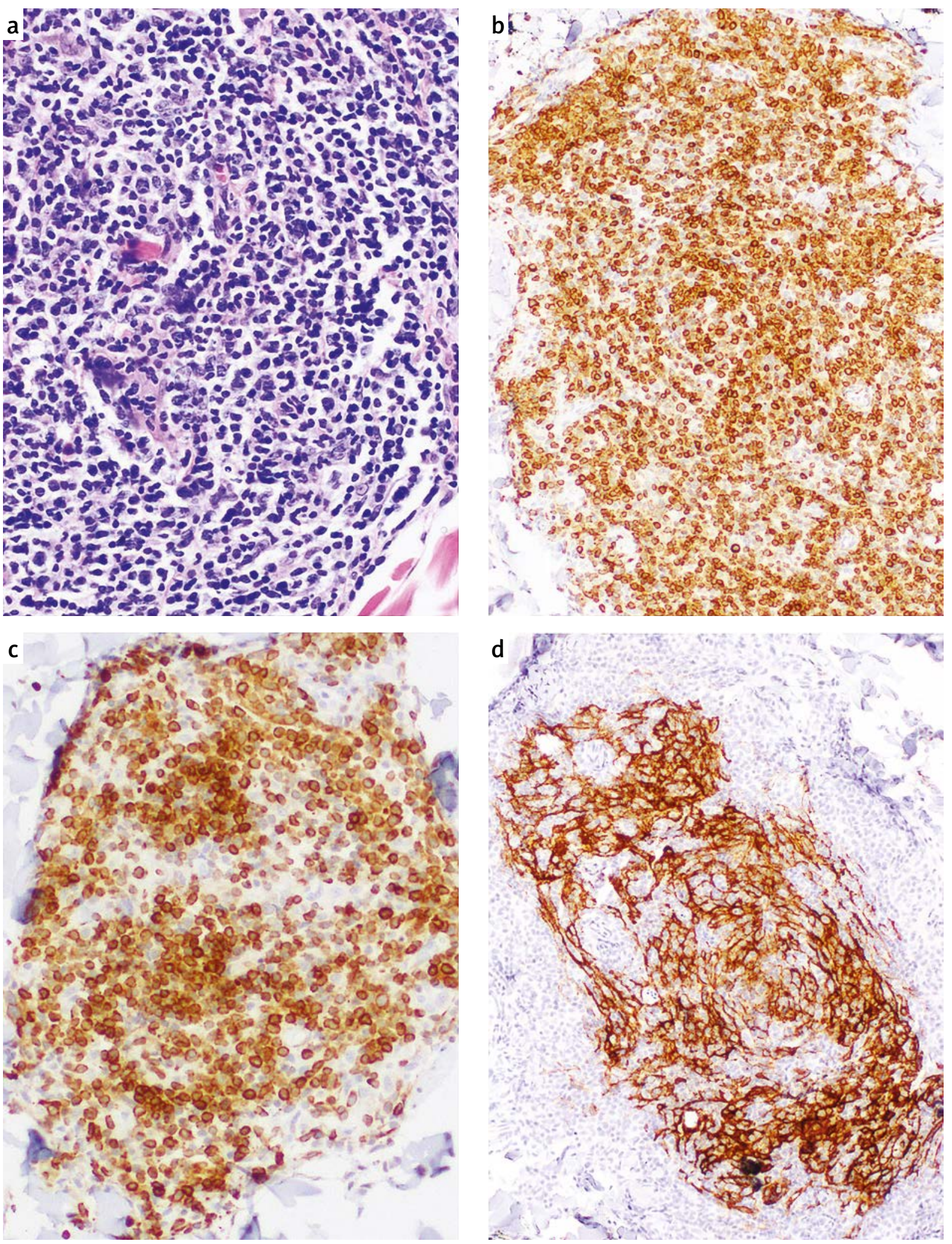

Fig. 4. Marginal zone B-cell lymphoma. Lymphoma cells "colonise" the structure of the follicles (a), express the CD-20 B-cell marker (b) and bcl2 protein (c), colonisation of the germinal centres, partially fragmented follicular dendritic cells - stained with CD21 antigen. 
tory and nervous systems and skin lesions, and with presence of cryoglobulins, and decreased C4 concentration, belong to the group at higher risk of lymphoma development [2, 4].

In the clinical case presented, only thorough immunohistochemical analysis of the biopsy specimens revealed the presence of lymphoma cells, while, for several years of the disease course, the histological picture alone failed to give grounds for putting forward a suggestion of a lymphoproliferative disease. Some types of B-cell lymphomas, including extranodal marginal zone lymphoma of MALT type, can resemble reactive lesions, due to slight cellular atypia. The application of immunohistochemical staining, together with the morphological picture and clinical data, make it possible to avoid erroneous diagnoses based exclusively on morphology assessment.

In summary, in patients with Sjögren's syndrome, in whom exacerbation of the disease or its atypical course may indicate development of a lymphoproliferative disease, it is necessary to perform a thorough clinical, imaging, histological and immunohistochemical assessment. The development of diagnostic methods, regular monitoring, correctly directed tests and new therapeutic methods can contribute to an improvement of the prognosis in this group of patients.

The authors declare no conflict of interest.

\section{References}

1. Bowman SJ, Ibrahim GH, Holmes G, et al. Estimating the prevalence among Caucasian women of primary Sjögren's syndrome in two general practices in Birmingham UK. Scand J Rheumatol 2004; 33: 39-43.

2. Pillemer SR, Matteson EL, Jacobsson LT, et al. Incidence of physician-diagnosed primary Sjögren syndrome in residents of Olmsted County, Minnesota. Mayo Clin Proc 2001; 76: 593-599.

3. Westhoff G, Zink A. Epidemiology of primary Sjörgren's syndrome. J Rheumatol 2010; 69: 41-49.

4. Dafni UG, Tzioufas AG, Staikos P, et al. Prevalence of Sjögren's syndrome in a closed rural community. Ann Rheum Dis 1997; 56: 521-525.

5. Ioannidis JP, Vassiliou VA, Moutsopoulos HM. Long-term risk of mortality and limfoproliferative disease and predictive classification of primary Sjögren's syndrome. Arthritis Rheum 2002; 46: 741-747.

6. Lazarus MN, Robinson D, Mak V, et al. Incidence of cancer in a cohort of patients with primary Sjögren's syndrome. Rheumatology 2006; 45: 1012-1015.

7. Kassan SS, Thomas TL, Moutsopoulos HM, et al. Increased risk of lymphoma in sicca syndrome. Ann Intern Med 1978; 89: 888-892.
8. Gasparotto D, De Vita S, De Re V, et al. Extrasalivary lymphoma development in Sjögren's syndrome. Arthritis Rheum 2003; 48: 3181-3186.

9. Engels EA, Cerhan JR, Linet MS, et al. Immune-related conditions and immune-modulating medications as risk factors for non-Hodgkin's lymphoma: a case-control study. Am J Epidemiol 2005; 162: 1153-1161.

10. Voulgarelis M, Dafni UG, Isenberg DA, Moutsopoulos HM. Malignant lymphoma in primary Sjögren's syndrome. Arthritis Rheum 1999; 42: 1765-1772. 